\title{
Analaysis of Students' Misconceptions on Structure and Function of Cell Organelle Using the Four-Tier Diagnostic Test
}

\author{
Sunarto, Rita Maghdalena Situmorang*, and Laurentius Sihotang
}

Department of Biology Education, Faculty of Education and Teacher Training, Universitas Kristen Indonesia, Cawang, Jakarta, 13510, Indonesia

Corresponding Email: ritamaghdalenas10@gmail.com

\begin{abstract}
The purpose of this research is to analyze misconceptions in high school students on the subject structure and function of cell organelles using a four-tier instrument diagnostic test at Senior High School 71 Jakarta. This study's sample was 97 students senior high school of class XI mathematics and science in the academic year 2019/2020 at 71 Senior High School Jakarta. The method used in this research was mixed methods and sequential explanatory model. The research method used is a descriptive survey. Survey data obtained from the test of instruments four-tier diagnostic test and the interviews with the respondents. Instruments developed in this research is 21 items and then tested for validity and reliability. The validity test obtained 18 instruments is valid at the level of $5 \%$ with a reliability value of 0,79 , meaning that the four-tier diagnostic test instrument can be used to analyze student misconceptions. Misconceptions occur in cell structure and organelles' subconcepts, cell organelle functions, peroxisomes and lysosomes, organelle cell and plant cell functions, and structural differences between animal cells and plant cells. The highest misconception occurred in the sub-concept of structure and cell organelles as much as $35.22 \%$. The lowest misconception occurred in the sub-concept of structural differences between animal cells and plant cells of $9.28 \%$.
\end{abstract}

\section{Keywords: Misconceptions, Structure and Function of Cell Organelle, Four-Tier Diagnostic Test}

\section{INTRODUCTION}

Learning is a process of interaction between teachers and students to achieve learning following what is expected (Susilana and Riyana, 2009). The development of one's knowledge of a concept influenced by cognitive experience (Suparno, 2013).

Understanding the concept is essential in learning. A concept is several theories related to an object, and the concept itself is represented in the form of words (Bahri, 2008). The misconception is a concept that is incompatible or in conflict with the scientists' concept before study an actual concept (Lee and Byun, 2012). Factors that lead to misconceptions among which the original concept (preconception) students (Bahar, 2003; Liu et al., 2009; Yates and Marek, 2014), the teacher does not fit on the field, that students use textbooks, teaching methods that are less right (Suparno, 2013). Misconceptions in students also due to abstract learning material, the number of foreign terms, language, difficulty and the lack of preparedness of students in receiving the material presented by teachers (Afidah, 2017; Fitria, 2014; Muna, 2016; Rochim et al., 2019; Zulvita et al., 2017).

. It is supported by research (Lazarowitz and Penso, 1992), which states that students who have difficulty understanding biology's subject matter, especially regarding physiological concepts abstract (can not be seen process directly). Student difficulties in understanding a cell's concept can make students have misconceptions (Sianturi and Gultom, 2016).

Low student learning outcomes can be influenced by various factors, one of which is a misconception. In addition to low learning outcomes of other factors, it can also affect student learning outcomes due to a lack of interest and motivation in learning (Jannah et al., 2017; Muna, 2015; Ramadhan et al., 2017; Sadhu et al., 2017; Widarti et al., 2016). The previous research showed that misconceptions appear on the sub- concept cell chemical components of $61.25 \%$, subconcept of structure and function of cells of $33.21 \%$, subconcept of plant and animal cell organelles by 
$31.75 \%$, and subconcept in membrane transport mechanisms by $31,67 \%$ (Mahardika, 2014).

Teachers can determine the material parts that require emphasis, and teachers can plan lessons more both to reduce the misconceptions students (Fariyani and Rusilowati, 2015; Wahyuningsih, T., Raharjo, T., \& Masithoh, 2013; Wilantika, 2018). Four-tier instrument knows better diagnostic test students' knowledge (Gurel et al., 2015; KaltakciGurel et al., 2017).

Based on the problem, the purpose of this research is (1) determine the validity and reliability of the instrument four-tier diagnostic test on the material structure and cell organelles, and (2) analyze the misconceptions students of Senior High School 71 Jakarta on material structure and cell organelles using a four-tier instrument diagnostic test.

\section{METHOD}

The population in this study were students of Senior High School 71 Jakarta. The sample used is a class XI student of Mathematics as many as 97 people who have studied the material structure and function of cell organelles. The method used in this study is a mixed-methods. Mixed method research combines the two methods, namely quantitative and qualitative research in a study or series of studies to understand the problems of research (Creswell, 2012, 2009).

The study design used is Explanatory Sequential Design (model verification sequence) which belong to the sequential model (combination order) (Sugiyono, 2016).

were conducted to confirm the test result data. This research was conducted with 4 stages: preparation, instrument- making phase, the implementation phase of research and processing and analysis of data (Eryilmaz, 2010; Karakuyu, 2011).

In item analysis, instruments is calculated for validity and reliability. For validity is used the product-moment, while the reliability is used KR-20 (Sugiyono, 2016). The analysis of students' conceptions would then calculate the percentage of students who understand the concepts, misconceptions, do not understand the concept and the error by using the formula $P=\frac{s}{J s} \times 100$ (Eryilmaz, 2010).

\section{RESULT AND DISCUSSION}

\subsection{Results Test Instruments}

Test the instrument's validity is done by using the product-moment correlation at a significance level of $5 \%$ by using SPSS version 20. From the calculation of the test's validity, 21 useful items consisted of 18 items. Table 1 is a summary of the results of validation at significance $5 \%$, obtained that the items are invalid at number 4,20 and 21, while the rest are valid

Table 1. Result of four-tier diagnostic

\begin{tabular}{|c|c|c|}
\hline \multirow{2}{*}{ No } & \multicolumn{2}{|c|}{ Validity } \\
\cline { 2 - 3 } & $\mathrm{r}_{\mathrm{xy}}$ & information \\
\hline 1 & 0.396 & valid \\
\hline 2 & 0.308 & valid \\
\hline 3 & 0.507 & valid \\
\hline 4 & 0.177 & invalid \\
\hline 5 & 0.533 & valid \\
\hline 6 & 0.403 & valid \\
\hline 7 & 0.428 & valid \\
\hline 8 & 0.487 & valid \\
\hline 9 & 0.656 & valid \\
\hline 10 & 0.337 & valid \\
\hline 11 & 0.449 & valid \\
\hline 12 & 0.396 & valid \\
\hline 13 & 0.563 & valid \\
\hline 14 & 0.336 & valid \\
\hline 15 & 0.544 & valid \\
\hline 16 & 0.382 & valid \\
\hline 17 & 0.344 & valid \\
\hline 18 & 0.673 & valid \\
\hline 19 & 0.593 & valid \\
\hline 20 & 0.092 & Invalid \\
\hline 21 & 0.142 & Invalid \\
\hline
\end{tabular}

Reliability testing using the test KuderRichardson 20 (KR-20), the results obtained after calculating was at 0.79 . The results prove that the problems have been made reliable into the category of "High" (Arikunto, 2010). 


\subsection{Misconception Analysis Students on material structures and organelles Cells Using Instruments Four-Tier Diagnostic Test.}

Comparison of percentage of the student of misconceptions on tier 1 , tier 2 , tier 3 and tier 4 based on the student's answers can be obtained at the student misconceptions about the percentage of tier 1 , tier 2 , tier 3 and tier 4 .

Table 3. The percentage of high school students' conceptions based on test results of the four-tier diagnostic test on cell organelles' material structure and function.

\begin{tabular}{|c|c|c|c|c|}
\hline \multirow{2}{*}{ No } & \multicolumn{4}{|c|}{ Tier 4 } \\
\cline { 2 - 5 } & $\begin{array}{c}\text { Understand } \\
\text { the Concept }\end{array}$ & $\begin{array}{c}\text { Not } \\
\text { Understood } \\
\text { Concept }\end{array}$ & error & $\begin{array}{c}\text { Misconcept } \\
\text { ions }\end{array}$ \\
\hline 1 & 62.89 & 17.53 & 1.03 & 18.56 \\
\hline 2 & 82.47 & 9.28 & 0 & 8.25 \\
\hline 3 & 46.39 & 26.80 & 0 & 26.80 \\
\hline 4 & 15.46 & 0 & 5.15 & 78.35 \\
\hline 5 & 25.77 & 27.84 & 6.19 & 37.11 \\
\hline 6 & 78.35 & 10.31 & 2.06 & 9.28 \\
\hline 7 & 68.04 & 15.46 & 1.03 & 15.46 \\
\hline 8 & 35.05 & 22.68 & 3.09 & 38.14 \\
\hline 9 & 29.90 & 20.62 & 30.93 & 18.56 \\
\hline 10 & 82.47 & 9.28 & 1.03 & 7.22 \\
\hline 11 & 56.70 & 2.06 & 1.03 & 40.21 \\
\hline 12 & 58.76 & 9.28 & 5.15 & 26.80 \\
\hline 13 & 70.10 & 10.31 & 3.09 & 14.43 \\
\hline 14 & 90.72 & 6.19 & 0,00 & 3.09 \\
\hline 15 & 65.98 & 13.40 & 4.12 & 16.49 \\
\hline 16 & 70.10 & 11.34 & 3.09 & 14.43 \\
\hline 17 & 83.51 & 5.15 & 1.03 & 10.31 \\
\hline
\end{tabular}

Table 3. shows the analysis misconception Junior High School 71 Jakarta on material structure and cell organelles using instruments four-tier diagnostic test shows the percentage of the highest misconceptions on the instrument number 4 as much as $78.35 \%$. Misconceptions percentage was lowest in instrument number 14 , as much as $3.09 \%$.

Table 4. Analysis misconceptions students based on test results using a four-tier instrument diagnostic test on the material structure and cell organelles.

\begin{tabular}{|c|c|c|c|}
\hline No & Subconceptd & No Matter & Percentage \\
\hline 1 & $\begin{array}{c}\text { Structure and cell } \\
\text { organelles }\end{array}$ & $\begin{array}{c}4,5,8,12, \\
13,18\end{array}$ & $35.22 \%$ \\
\hline 2 & $\begin{array}{c}\text { The function of the } \\
\text { cell organelles }\end{array}$ & $\begin{array}{c}1,2,11,14, \\
17,19\end{array}$ & $18.73 \%$ \\
\hline 3 & $\begin{array}{c}\text { Peroxisomes and } \\
\text { lysosomes }\end{array}$ & 9,16 & $16.49 \%$ \\
\hline 4 & The function of the & $3,7,10,15$, & $27.32 \%$ \\
\hline
\end{tabular}

\begin{tabular}{|c|c|c|c|}
\hline & $\begin{array}{c}\text { cell organelles of } \\
\text { animal and plant } \\
\text { cells }\end{array}$ & 20,21 & \\
\hline 5 & $\begin{array}{c}\text { Differences between } \\
\text { the structure of } \\
\text { animal cells and } \\
\text { plant cells }\end{array}$ & 6 & $9.28 \%$ \\
\hline
\end{tabular}

\subsection{Discussion}

Here are described further analysis misconceptions students based on test results and interviews:

\subsubsection{The structure of cell organelles}

In question number 5 , misconceptions that occur with results from interviews with 97 students and 55 students argued that the plasma membrane phospholipid structure has the region and hydrophilic regions due to the plasma membrane and organelle membrane a double layer (bilayer). In the interior of the membrane, tail phospholipids are phospholipids and proteins interior section. The Head of the phospholipid tail is hydrofoil. Based on the students' answers, the pattern of misconceptions that occur in the amount of $8.24 \%$ that answered the plasma membrane structure, a hydrophilic region and the region for the plasma membrane protein and organelle membranes consist of a double layer (bilayer). In the interior of the membrane, tail phospholipids are phospholipids and proteins interior section. The Head of the phospholipid tail is hydrofoil.

At number 8, this misconception follows the results of interviews with 80 students who say that lysosomes characterized in that the structure of cisterns or sheet-shaped organelles consists of two layers of the membrane. Lysosome function as protein synthesis. Based on the students' answers, the pattern of misconceptions occurs in the amount of $13.40 \%$.

In numbers 12 , this misconception following the results of interviews with 58 students who say that mitochondria are the cell that regulates the movement of substances into and out of cells. Based on the students' answers, the misconceptions pattern that occurs is equal to $15.46 \%$ who answered that the cell wall is the cell that regulates the movement of substances into and out of cells. 


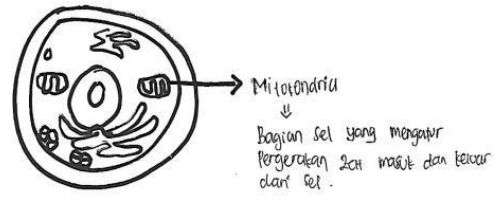

Pictures 1. Pictures interviews with students 58

At number 13, students' misconceptions are based on interviews with 68 students and 44 students who say that the matrix is a fold and cristae is fluid. Based on the results of the students' answers, pattern of misconceptions that occur in the amount of $3.09 \%$ who answered that in the picture about the number 13 that is the image of the ribosome structure contained outer membrane, inner membrane, and the cristae.

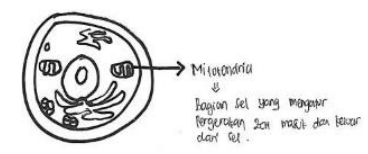

Pictures 2. Pictures interviews with students 44

At number 18, misconceptions that occur in students based on interviews with 58 students and 76 students about the inner structure of chloroplasts say that thylakoid stacks are contained in the chloroplast stroma grana are round-shaped pile in the chloroplasts. Based on the students' answers, misconceptions pattern that occurs that is equal to $21.65 \%$ who answered that parts of chloroplasts in question number 18 which is the outer membrane, thylakoids, granum, lumen, stroma, the inner membrane. Based on the students 'answers to students' wrong sort, the parts of the chloroplast, which is supposed to be part of the chloroplast shown on the matter of the number 18 is the number 1 outer membrane, two thylakoids, three lumens, four thylakoids, stroma 5, 6 membranes.

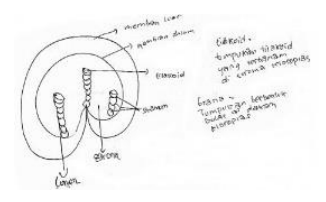

Pictures 3. Pictures interviews with 76 students

Analysis of misconception in this study was supported by the study results (Mahardika, 2014). The results showed that the students had misconceptions by understanding the concept of structure and cell organelles.

\subsubsection{The function of the cell organelles}

The misconception that occurs in numbers 14 based on interviews with 74 students suggests that the cell contains a lot of DNA than the cell wall. Based on the students' answers, the pattern of misconceptions that occur in the amount of $2.06 \%$ who answered that cells containing much DNA that the cell wall because the organic component developed it.

The misconception that occurred at about number 17 based on interviews with students 20 and students 58 which suggests that the organelles known as The Power of House or an energy producer for the cell are the ribosome because ribosomes are organelles (parts of cells) that function to expend energy to cell metabolism, to produce ATP (adenosine Tripospat) of nutrients and oxygen. The Power of House or an energy producer for the cell is mitochondria. Based on the students' answers pattern of misconceptions occur in the amount of $10.31 \%$.

The misconception that occurs in numbers 19 based on interviews with 44 students and 45 students who argued that cell organelles' function to form lysosomes and maintain the plant cell wall is a micro-entity for micro-entities require some lysosomal enzymes. Lysosomal enzymes produced endoplasmic reticulum is then entered into the cisternae in the Golgi apparatus. Based on the students' answers pattern of misconceptions, they occur in the amount of $14.43 \%$.

Analysis of misconception in this study was supported by the study results (Hasibuan, H. H \& Harahap, F, 2016). The study results showed that the students had misconceptions by understanding the concept of the cell organelles' function.

\subsubsection{Peroxisomes and lysosomes}

Analysis of student misconceptions in subconcepts peroxisomes and lysosomes occurs because students understand the concept is wrong in explaining peroxisomes and lysosomes. In question number 9, misconceptions occur with results from interviews with 19 students and 48 students who argued that peroxisome contains peroxidase and oxidase enzymes, lysosomes containing hydrolytic and outlines peroxidase $\left(\mathrm{H}_{2}\right)$ into oxygen. Based on the students' answers, pattern of misconceptions occur in the amount of $13.40 \%$. 


\subsubsection{The function of the cell organelles of animal and plant cells}

The misconception that occurs in about number 20 supported by interviews with students 76 and students 58, which suggests that microtubules are part of the cell that has the shape of a tube and has an order of microtubules arranged radially found in virtually all eukaryotic cells, because the organelles are found in eukaryotic cells which have a role in cell respiration and the formation of cilia and flagella. Based on the students' answers, pattern of misconceptions occur in the amount of $44.33 \%$.

Analysis of misconception in this study was supported by the study results (Mahardika, 2014). The results showed that the students had misconceptions by understanding the function of cell organelles of animal and plant cells.

\subsubsection{Differences between the structure of animal cells and plant cells.}

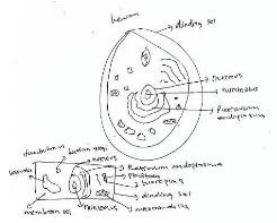

Picture 4. Picture interviews with students

Analysis of student misconceptions in subconcepts structural differences between animal cells and plant cells occurs because students understand the concept is wrong in explaining the differences between the structure of animal cells and plant cells. In question number 6 , misconceptions that occur with results from interviews with students 20 , who argued that the differences between the structure of animal cells and plant cells, namely that animal cells have a cell wall, if the plant cells lack a cell wall because the shape of animal cells are not fixed so it is difficult to divide themselves, then the cell wall surrounds the cell cytoplasm can divide, plant cell shape anyway so do not need and do not have a cell wall.

The results of interviews with 97 students express differences between the structure of animal cells and plant cells in animal cells is that there are no mitochondria in plant cells there.

\section{CONCLUSION}

Based on the results of analysis of the misconceptions concept and structure of cell organelles in Senior Hogh School 71 Jakarta students are using a four-tier diagnostic test, researchers can make some conclusions, namely:

a. Four-tier instrument diagnostic test on the material structure and function of cell organelles can be viewed from 21 questions in the test, 18 questions valid at 5\% and amounted to 0.79 realities. Four-tier instrument valid and reliable diagnostic test means that the instrument can be used for research analysis to misconceptions SMA Negeri 71 Jakarta on material structure and cell organelles.

b. The results of the analysis in class XI student misconceptions Mathematics 1,2 and 4 on the concept

structure and cell organelles using a four-tier instrument diagnostic test showed misconceptions occur in subconcepts cell organelle structure and function of cell organelles, peroxisomes and lysosomes, organelles function of animal cells and plant cells, and the structural difference between animal cells and plant cells. The misconception is highest in subconcepts structure and cell organelles as much as $35.22 \%$. The lowest misconception occurs in subconcepts structural differences between animal cells and plant cells, as much as $9.28 \%$.

\section{REFERENCES}

[1] Afidah, M., 2017. Identifikasi Pola Miskonsepsi Mahasiswa Pada Konsep Mekanisme Evolusi Menggunakan Certainty Of Response Index (CRI). Bio-Lectura. https://doi.org/10.31849/bl.v4i2.394

[2] Arikunto, S., 2010. Prosedur Penelitian Suatu Pendekatan Praktik. PT. Rineka Cipta, Jakarta.

[3] Bahar, M., 2003. Misconceptions in biology education and conceptual change strategies. Educ. Sci. Theory Pract.

[4] Creswell, J.W., 2012. Educational Research: Planning, Conducting and Evaluating Quantitative and Qualitative Research. Pearson, London.

[5] Creswell, J.W., 2009. Research design: Qualitative, quantitative, and mixed methods approaches (3rd ed). Res. Des. Qual. Quant. Mix. methods approaches. https://doi.org/10.1016/j.math.2010.09.003

[6] Djamarah, S. B., 2008. Psikologi pendidikan.Rineka Cipta, Jakarta.

[7] Eryilmaz, A., 2010. Development and application of three-tier heat and temperature test: Sample of bachelor and students graduate. Edit. Arastirmalari - 
Eurasian J. Educ. Res.

[8] Fariyani, Q., Rusilowati, A., 2015. Pengembangan Four-Tier Diagnostic Test Untuk Mengungkap Miskonsepsi Fisika Siswa SMA Kelas X. J. Innov. Sci. Educ. 4.

[9] Fitria, A., 2014. Miskonsepsi Mahasiswa Dalam Menentukan Grup Pada Struktur Aljabar Menggunakan Certainty Of Response Index (Cri) Di Jurusan Pendidikan Matematika IAIN Antasari. J. Pendidik. Mat. https://doi.org/10.18592/jpm.v1i2.50

[10] Gurel, D.K., Eryilmaz, A., McDermott, L.C., 2015. A review and comparison of diagnostic instruments to identify students' misconceptions in science. Eurasia J. Math. Sci. Technol. Educ. https://doi.org/10.12973/eurasia.2015.1369a

[11] Jannah, M., Ningsih, P., Ratman, R., 2017. Analisis Miskonsepsi Siswa Kelas XI SMA Negeri 1 Banawa Tengah Pada Pembelajaran Larutan Penyangga Dengan CRI (Certainty of Response Index). J. Akad. Kim. https://doi.org/10.22487/j24775185.2016.v5.i2.8019

[12] Kaltakci-Gurel, D., Eryilmaz, A., McDermott, L.C., 2017. Development and application of a four-tier test to assess pre-service physics teachers' misconceptions about geometrical optics. Res. Sci. Technol.

Educ. https://doi.org/10.1080/02635143.2017.1310094

[13] Karakuyu, Y., 2011. Elektrik Konusunda Kavram Yanılgıları ve Kavramsal Değişim Yaklaşımı. Gaziantep Univ. - J. Soc. Sci.

[14] Lazarowitz, R., Penso, S., 1992. High school students' difficulties in learning biology concepts. J. Biol. Educ. https://doi.org/10.1080/00219266.1992.9655276

[15] Lee, G., Byun, T., 2012. An Explanation for the Difficulty of Leading Conceptual Change Using a Counterintuitive Demonstration: The Relationship Between Cognitive Conflict and Responses. Res. Sci. Educ. https://doi.org/10.1007/s11165-011-92345

[16] Liu, T.C., Lin, Y.C., Tsai, C.C., 2009. Identifying senior high school students' misconceptions about statistical correlation and their possible causes: An exploratory study using concept mapping with interviews. Int. J. Sci. Math. Educ. https://doi.org/10.1007/s10763-008-9142-y

[17] Mahardika, R., 2014. Identifikasi miskonsepsi siswa menggunakan Certainty Of Response Index (CRI) dan wawancara diagnosis pada Konsep sel.

[18] Muna, I.A., 2016. Identifikasi Miskonsepsi Mahasiswa PGMI Pada Konsep Hukum Newton Menggunakan Certainty of Response Index (CRI). Cendekia J. Educ. https://doi.org/10.21154/cendekia.v13i2.251

[19] Muna, I.A., 2015. Newton Menggunakan Certainty of Response Index ( Cri ). Cendekia.

[20] Ramadhan, M., Sunardi, Kurniati, D., 2017. Analisis Miskonsepsi Siswa Dalam Menyelesaikan Soal Matematika Berstandar PISA Dengan Menggunakan Certainty of Response Index (CRI). J. Pendidik.
Mat.

[21] Rochim, F.N., Munawaroh, F., Yuniasti, A., Wulandari, R., 2019. Identifikasi Profil Miskonsepsi Siswa Pada Materi Cahaya Menggunakan Metode Four Tier Test Dengan Certainty of Response Index ( Cri ). Nat. Sci. Educ. Reseach.

[22] Sadhu, S., Tima, M.T., Cahyani, V.P., Laka, A.F., Annisa, D., Fahriyah, A.R., 2017. Analysis of acidbase misconceptions using modified certainty of response index (CRI) and diagnostic interview for different student levels cognitive. Int. J. Sci. Appl. Sci. Conf. Ser https://doi.org/10.20961/ijsascs.v1i2.5126

[23] Sianturi, S., Gultom, T., 2016. Analisis Kesulitan Belajar dan Hubungannya Dengan Hasil Belajar Siswa Pada Mata Pelajaran Biologi Siswa Kelas X di SMA Negeri 1 Sidikalang Tahun Pembelajaran 2015/ 2016. J. PELITA Pendidik.

[24] Sugiyono, 2016. Metode Penelitian Pendidikan Pendekatan Kuantitatif, Kualitatif, dan R\&D. Alfabeta, Bandung.

[25] Suparno, P., 2013. Miskonsepsi \& Perubahan Konsep Dalam Pendidikan Fisika. Gramedia Widiasarana, Jakarta.

[26] Susilana, R., Riyana, C., 2009. Media Pembelajaran Hakikat, Pemanfaatan dan Penilaian. Wacana Prima, Bandung.

[27] Wahyuningsih, T., Raharjo, T., \& Masithoh, D.F., 2013. Pembuatan Instrumen Tes Diagnostik Fisika SMA Kelas XI. J. Pendidik. Fis.

[28] Widarti, H.R., Permanasari, A., Mulyani, S., 2016. Student misconception on redox titration (A challenge on the course implementation through cognitive dissonance based on the multiple representations). J. Pendidik. IPA Indones. https://doi.org/10.15294/jpii.v5i1.5790

[29] Wilantika, N., 2018. Pengembangan Penyusunan Instrumen Four-Tier Diagnostic Test Untuk Mengungkap Miskonsepsi Materi Sistem Ekskresi di SMA Negeri 1 Mayong Jepara. Phenom. J. Pendidik. MIPA. https://doi.org/10.21580/phen.2018.8.2.2699

[30] Yates, T.B., Marek, E.A., 2014. Teachers teaching misconceptions: A study of factors contributing to high school biology students' acquisition of biological evolution-related misconceptions. Evol. Educ. Outreach. https://doi.org/10.1186/s12052-0140007-2

[31] Zulvita, Halim, A., Kasli, E., 2017. Identifikasi dan remediasi miskonsepsi konsep hukum newton dengan menggunakan metode eksperimen di man darussalam. J. Ilm. Mhs. Pendidik. Fis. 